\title{
PENINGKATAN KAPASITAS WIRAUSAHA PEREMPUAN MELALUI USAHA RUMAH TANGGA
}

\author{
Grace Jenny Soputan
}

\author{
Jurusan Manajemen, Fakultas Ekonomi, Universitas Negeri Manado \\ *Penulis Korespodensi : gracesoputan@unima.ac.id
}

\begin{abstract}
Abstrak
Kacang sangrai adalah produk usaha rumah tanggayang dihasilkan oleh sebagian besar pelaku usaha mikroyang ada di Kelurahan Kinali 1 Kawangkoan. Tujuan dari kegiatan Ipteks bagi Masyarakat untuk memfasilitasi para pelaku usaha mikro kacang sangrai dalam meningkatkan kualitas produk melalui pengemasan dengan sentuhan teknologi dan manajemen usaha. Target khusus yaitu untuk merubah pola pikir dan perilaku mitra dalam memproduksi dan menjual produk kacang sangrai supaya bisa mendapatkan keuntungan yang lebih besar. Untuk merealisasikan program tersebut, metode yang digunakan dalam kegiatan ini antara lain metode sosialisasi, edukasi/penyuluhan, implementasi teknologi, dan pendampingan. Hasil yang dicapai terfasilitasinya kegiatan usaha kacang sangrai pada kelompok usaha perempuan Mawali-wali yaitu pengemasan produk yang lebih menarik dengan beberapa variasi ukuran, manajemen usaha termasuk keuangan, dan pemasaran.
\end{abstract}

Kata Kunci: Kacang sangrai, pengemasan, usaha rumah tangga

\begin{abstract}
Roasted beans are home business products produced by most micro business actors in Kelali Kinali 1 Kawangkoan. The purpose of science and technology for the community to facilitate the perpetrators of roasted bean micro-business in improving product quality through packaging with a touch of technology and business management. Specific targets are to change the mindset and behavior of partners in producing and selling roasted bean products in order to obtain greater benefits. To realize the program, the methods used in this activity include methods of socialization, education / counseling, technology implementation, and mentoring. The results achieved the business activities of roasted beans in the group of women business Mawali-wali is packaging more interesting products with several variations of size, business management including finance, and marketing.
\end{abstract}

Keywords: Roasted beans, packaging, household business

\section{PENDAHULUAN}

Kacang tanah adalah tumbuhan berasal dari Amerika Selatan tepatnya adalah Brazillia, namun saat ini telah menyebar ke seluruh dunia yang beriklim tropis atau subtropis Masuknya kacang tanah ke Indonesia pada abad ke-17 diperkirakan karena dibawa oleh pedagang-pedagang Spanyol,Cina,atau Portugis sewaktu melakukan pelayarannya dari Meksiko ke Maluku setelah tahun 1597 Pada tahun 1863 Holle memasukkan Kacang Tanah dari Inggris dan pada tahun 1864 Scheffer memasukkan pula Kacang Tanah dari Mesir Republik Rakyat Tiongkok dan India kini merupakan penghasil kacang tanah terbesar dunia (Wikipedia)

Kacang sangrai adalah kacang tanah yang diolah dengan menggunakan pasir halus sampai menjadi matang. Pengolahan kacang sangrai merupakan pekerjaan sebagian besar masyarakat Kinali 1 Kawangkoan yang sudah berlangsung sejak puluhan tahun yang lalu. Usaha kacang sangrai secara turun temurun dilaksanakan oleh masyarakat setempat. Kegiatan pengolahan kacang sangrai dilakukan secara orang per orang, ada yang skala besar dan ada juga skala kecil. Jika kita melewati tempat ini hampir setiap rumah tangga menekuni usaha ini. Banyak suka duka yang dialami oleh setiap keluarga yang mengelola usaha kacang sangrai tersebut, yaitu masalah bahan baku yang tidak setiap saat tersedia, dan juga modal kerja yang dimiliki kurang memadai sehingga mengganggu kelancaran produksi kacang sangrai. 

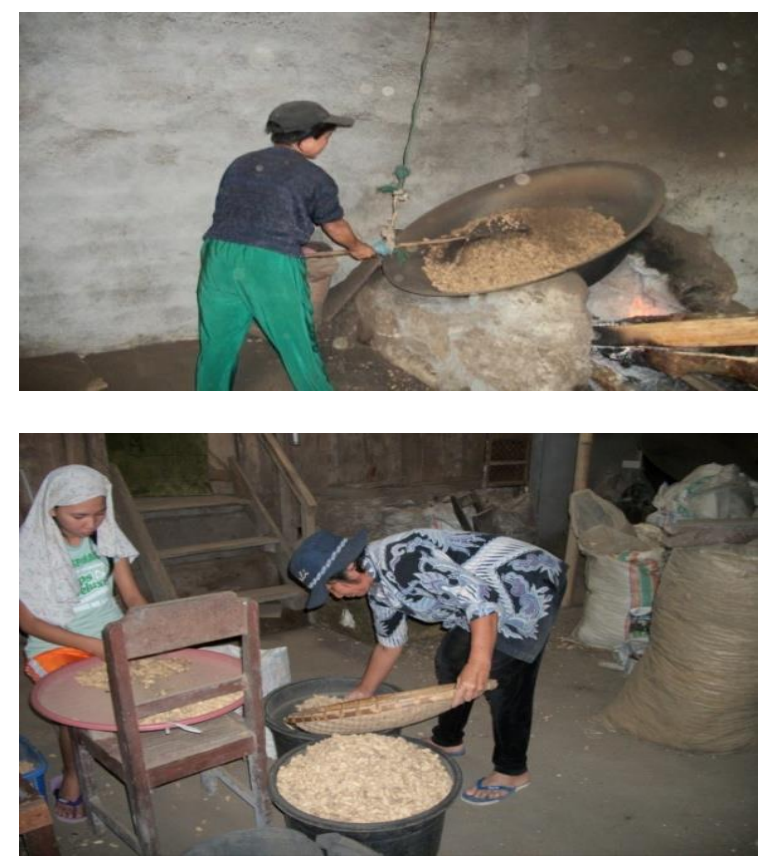

Gambar 1.1. Proses pengolahan kacang sangria

Permasalahan yang dialami oleh pelaku usaha kacang sangrai adalah modal untuk membeli bahan baku kacang sangat terbatas sehingga bahan bakunya hanya dalam jumlah sedikit yang diproses menjadi kacang sangrai. Modal yang terbatas membuat para pengolah (ibu-ibu) harus meminjam uang untuk menambah modal guna dapat membeli bahan baku yang lebih banyak. Untuk menutupi biaya produksi maka hasil kacang sangrai dijual dalam jumlah besar (per karung) dengan harga yang relatif murah sekitar Rp 8.000 per liter, tujuannya supaya modal yang telah dikeluarkan cepat kembali. Padahal jika mereka menjual secara eceran akan lebih menguntungkan, atau walaupun dalam jumlah besar (borongan) tetapi jika sudah dikemas dengan beberapa variasi akan lebih besar keuntungan yang diperoleh. Kadangkadang para pedagang atau pihak toko di Manado mengatur harga jual kacang tersebut, dan para pengelola kacang tidak mampu bernegosiasi harga karena sudah membutuhkan uang. Masalah lain yang terjadi para pedagang atau toko meminjamkan modal kepada ibu-ibu sebagai pengelola kacang dan akhirnya mau tidak mau pihak toko yang mengatur harga jual kacang tersebut.Masalah modal sebenarnya dapat diatasi melalui akses perbankan, tetapi kenyataannya pihak perbankan tidak memberikan kesempatan kepada para pengusaha mikro ini karena dari segi pembukuan, memang masih kurang. Kelemahan dari semua pelaku usaha ini belum memiliki pembukuan yang benar seperti buku kas, buku pembelian, buku penjualan, dan buku harian.

Bertahun-tahun para pelaku usaha mikro kacang sangrai yang ada di Kinali 1 pertumbuhan usahanya agak lambat padahal peluang pasar untuk kacang sangrai sangat terbuka apalagi saat ini kegiatan pariwisata di Sulawesi Utara cukup meningkat.
Kacang sangrai sebagai produk ole-ole (souvenir) sudah dikenal luas karena rasanya enak tidak kalah dengan kacang sejenis asal pabrikan. Wisatawan yang datang ke Manado pasti akan membeli ole-ole termasuk kacang sangrai tersebut.

Kondisi para pelaku usaha mikro kacang sangrai ini harus diperbaiki dengan jalan meningkatkan kualitas produknya melalui pengemasan produk yang berkualitas dan menarik yang sesuai dengan kebutuhan pelanggan. Jika untuk para wisatawan maka produk harus dikemas dalam ukuran yang relatif kecil (1 liter, 250 gram, 500 gram). Bagi pelanggan yang bukan wisatawan, maka produk dapat dikemas dalam ukuran misalnya 2 liter, $1 \mathrm{~kg}, 2$ $\mathrm{kg}$. Para pengolah kacang sangrai ini harus menjual produk yang sudah dikemas, jangan lagi menjual curah atau per karung, sehingga keuntungannya akan lebih meningkat. Permasalahan mereka adalah kualitas produk belum baik dalam arti produk kacang sangrai tidak dikemas dengan kemasan yang berkualitas dalam ukuran yang bervariasi karena hanya dijual curah atau per karung. Jadi kemasannya dalam karung saja.

Harga yang ditetapkan Rp 8.000,- tanpa dikemas atau dengan kata lain produk ini dijual dalam kemasan karung berukuran besar. Jadi usaha ini tidak menjual produk secara eceran, misalnya dikemas dalam ukuran 1 liter atau $1 \mathrm{~kg}$. Dilihat dari harganya memang relatif murah karena dijual tanpa kemasan atau istilahnya jual curah. Jika produk ini dikemas dalam berbagai ukuran dan kemasannya menarik, maka harganya akan lebih tinggi. Dalam pemasaran, suatu produk dapat diminati oleh konsumen sangat dipengaruhi oleh beberapa faktor, antara lain harganya relatif terjangkau, kualitasnya baik, mudah didapat, dan tidak kalah penting adalah menarik. Walaupun mutunya baik tetapi bentuknya, warnanya, dan kemasannya tidak begitu menarik, maka para konsumen atau calon konsumen tidak tertarik untuk membelinya.

Selama ini berdasarkan data yang tim dapatkan di sekitar Kawangkoan, toko-toko yang menjual kacang sangrai, proses pengemasannya dilakukan oleh toko yang menjual produk tersebut. Jika dikalkulasi kemungkinan keuntungan yang lebih besar adalah para penjual di toko bukan pelaku usaha yang memproduksinya. Kelompok Mitra menjual produk kacang sangrai per liter Rp 8.000,- karena tidak dikemas. Toko yang menjual langsung ke konsumen mengemas dalam ukuran $0,5 \mathrm{~kg}$ atau sekitar 2 liter dengan kemasan plastik bening dan dijual menjadi Rpn 30.000,- per pak. Keuntungan mereka sekitar Rp 14.000,- sampai dengan Rp 20.000,- per pak. Sedangkan mitra keuntungannya lebih kecil karena dia harus membayar tenaga kerja dan lain-lain. Menurut pengamatan kami kelompok mitra memberikan keuntungan besar kepada para penjual yang ada di toko-toko. Makanya mitra yang sudah 
berusaha sekitar 10 sampai 15 tahun kemajuannya belum signifikan, artinya belum berkembang maju. Ironis memang, kelompok mitra yang memproduksi kacang sangrai mereka memperoleh keuntungan lebih kecil dari pihak toko yang menjual kepada konsumen. Padahal proses pengemasan tidak serumit proses produksi.
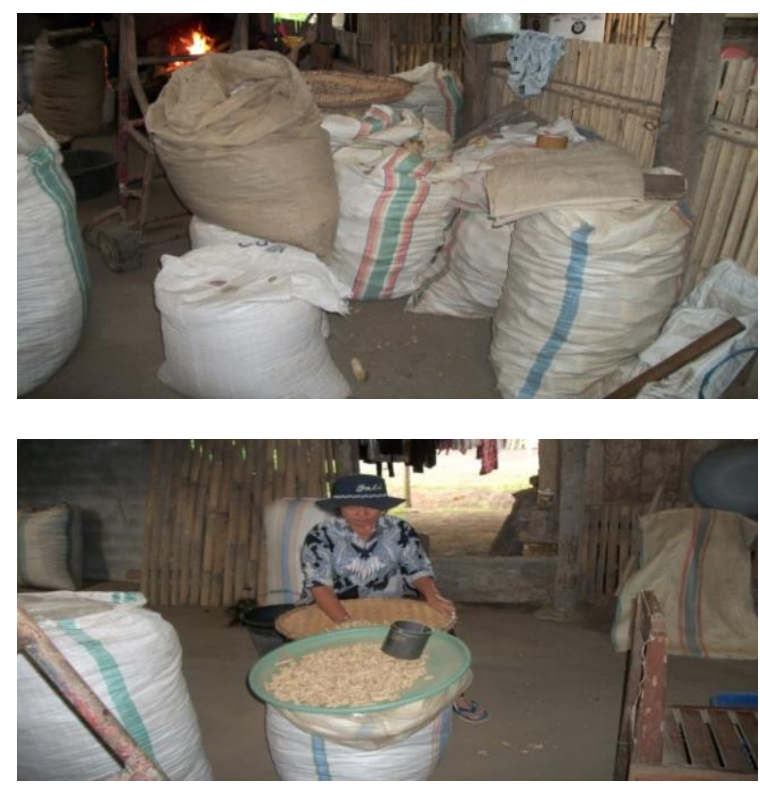

Gambar 1.2. Kacang sangrai dikemas dalam karung dan dijual per karung

Pemasalahan yang diatasi pada mitra dalam kegiatan Ipteks bagi Masyarakat adalah difokuskan pada peningkatan kualitas produk sehingga meningkatkan nilai tambah dari kacang sangrai. Dengan demikian dapat meningkatkan pendapatan mitra. Kegiatan ini juga difokuskan pada aspek pemasaran dengan memperluas jaringan pemasaran.

\section{BAHAN DAN METODE}

Bertolak dari permasalahan mitra maka solusi yang dilakukan adalah untuk menjawab permasalahan keterbatasan pengetahuan tentang kualitas produk dalam hal ini pengemasan produk kacang sangrai. Solusi dalam permasalahan ini dengan memberikan pengetahuan dan ketrampilan tentang pengemasan produk yang bervariasi dengan sentuhan teknologi, supaya dapat meningkatkan nilai tambah dan keuntungan mitra. Metode atau strategi pendekatan yang diterapkan dalam kegiatan ini,pelaksana melakukan pendampingan dan memfasilitasi keseluruhan proses pelaksanaan kegiatan, juga telah melibatkan staf pihak Dinas Perindustrian dan Perdagangan Provinsi Sulawesi Utara. Metode yang diterapkan dapat dirinci sebagai berikut:

1. Sosialisasi/penyuluhan.

Metode ini digunakan untuk memberikan wawasan tentang kewirausahaan dan meningkatkan pemahaman pengetahuan dan ketrampilan dalam hal pengemasan produk yang lebih menarik. Metode ini juga digunakan untuk meningkatkan pengetahuan mitra tentang manajemen usaha termasuk pembukuan. Selain itu metode penyuluhan digunakan dalam peningkatan pemahaman tentang kesehatan pangan yang dilakukan oleh Dinas Kesehatan dalam rangka menerbitkan sertifikat pangan dengan nomor P-IRT. Penyuluhan ini penting untuk proses penerbitan nomor P-IRT, karena akan menambah kualitas suatu produk.

2. Pelatihan

Metode ini digunakan untuk memberikan ketrampilan kepada mitra dalam pengemasan produk, dengan menggunakan kemasan yang menarik dan alat untuk mengemas (Sealer)

3. Pendampingan

Metode ini digunakan untuk memberikan semangat berwirausaha kepada mitra dan dalam proses pengemasan. Metode ini juga digunakan pada kegiatan pembukuan dan melatih mitra dalam mengelola usaha (manajemen) serta pemasaran produk.

Subjek yang diberikan penyuluhan, pelatihan dan pendampingan adalah para perempuan yang dikelompokkan dan diberi nama Kelompok Usaha Perempuan Mawali-wali kelurahan Kinali I, Kecamatan Kawangkoan, Kabupaten Minahasa, Provinsi Sulawesi Utara. Kelompok ini terdiri dari 12 anggota. Kegiatan Ipteks bagi Masyarakat dilaksanakan selama 8 bulan sejak Januari s/d Agustus 2017.

\section{HASIL DAN PEMBAHASAN}

\section{A. Peningkatan Pengetahuan tentang} Kewirausahaan

Pengetahuan tentang kewirausahaan para perempuan yang tergabung dalam usaha mikro kacang sangrai yang ada di kelurahan Kinali 1 Kecamatan Kawangkoan sebelum dilakukan kegiatan Ipteks bagi Masyarakat masih rendah. Hal ini ditunjukkan oleh perajin kacang sangrai adalah jika tidak ada bahan baku karena tidak mempunyai modal, maka pengolahan produk tersebut tidak jalan. Selain itu belum mampu berinovasi dalam meningkatkan kualitas produk, karena mereka hanya menjual produk dalam jumlah besar (per karung) atau menjual eceran per liter (kemasannya hanya tas kresek). Dalam hal pemasaran, produk mereka tidak bias masuk ke toko-toko kue dan souvenir di Kota Manado karena tidak memiliki nomor P-IRT (nomor ini dapat memberikan jaminan bahwa produk pangan ini layak untuk dikonsumsi dari segi kesehatan dan kebersihan).

Setelah dilaksanakan kegiatan Ipteks bagi Masyarakat ini terdapat peningkatan pemahaman/pengetahuan dalam hal kewirausahaan yaitu bagaimana menambah nilai kreativitas terhadap produk yang dihasilkan oleh kelompok mitra ini. Hasilnya saat ini produk yang dijual sudah dikemas dalam beberapa ukuran yang kualitasnya lebih baik. Selain itu terdapat peningkatan mental/jiwa 
wirausaha yaitu ditunjukkan melalui perilaku pantang menyerah meskipun mengalami pasang surut kegiatan usaha mereka. Perilaku mental ingin maju sudah nampak pada anggota kelompok yaitu salah satu perilaku yang ditunjukkan anggota pengurus sudah berpartisipasi dalam pertemuan dengan pihak perbankan yang difasilitasi oleh Dinas Perindustrian dan Perdagangan Provinsi Sulawesi Utara.

\section{B. Peningkatan Kualitas Produk Kacang Sangrai}

Produk kacang sangrai yang dihasilkan setelah dilakukan proses penyuluhan dan pendampingan terjadi peningkatan kualitas dengan kemasan yang menarik berbentuk pouch dan toples tabung. Kemasan ini dapat menjamin produk kacang sangrai dapat bertahan lama dan tidak mudah rusak oleh udara dan angin. Berbeda dengan kemasan sebelumnya produk kacang sangrai hanya dikemas dalam karung dan dijual per karung kepada toko dan toko yang akan mengemas produk kacang sangrai dan diberi label nama toko tersebut. Dari kasus tersebut jika dikalkulasi yang mendapatkan keuntungan besar adalah toko yang menjual langsung kepada konsumen yang telah dikemas sendiri oleh toko. Keuntungan yang besar diraup oleh toko padahal mereka tidak mengalami proses produksi yang panjang.

Proses produksi pengolahan kacang sangrai dimulai dari pemilihan bahan baku kacang tanah yang berkualitas. Kacang tanah di Kawangkoan ada dua jenis yaitu kacang merah dan kacang belimbing. Kacang tanah yang masih berupa bahan baku dijemur sampai kering, sesuah itu disangrai dengan menggunakan media pasir halus. Setelah matang, kacang tersebut di bersihkan dan dipilih yang kualitas baik untuk dikemas. Proses pengemasan menggunakan media toples tabung dan media plastik pouch (lihat gambar 1.3)

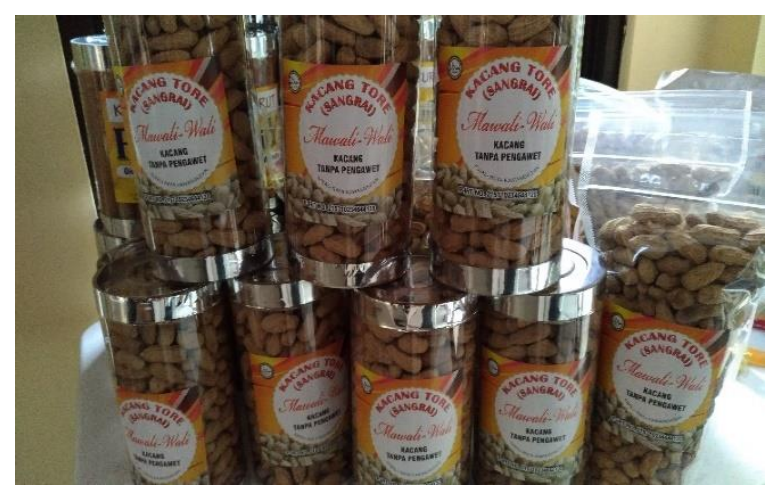

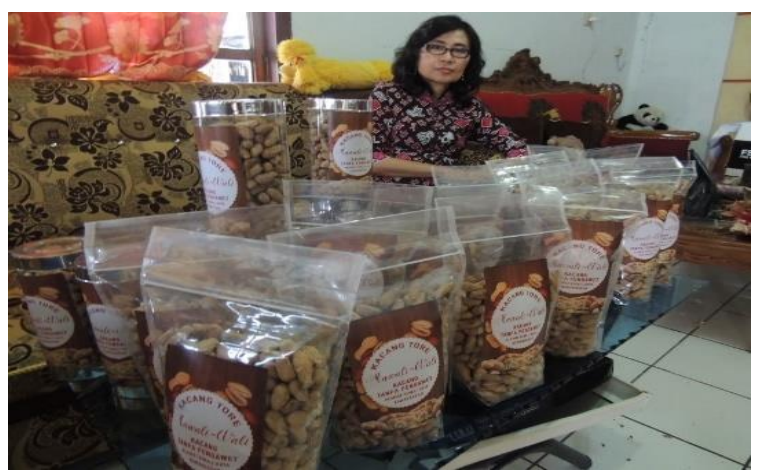

Gambar 1.3. Produk yang telah dikemas

\section{Peningkatan Pendapatan}

Ironis situasi yang tergambar dalam situasi para pelaku usaha kacang sangrai yang di kelurahan Kinali 1 Kawangkoan yang merupakan subjek dari kegiatan Ipteks bagi Masyarakat. Seperti situasi yang digambarkan dalam pendahuluan, bahwa pendapatan atau keuntungan yang diperoleh para pengolah kacang sangrai relative lebih kecil dari pada keuntungan yang diperoleh para toko-toko yang menjual produk tersebut dengan kemasan tertentu.

Setelah dilakukan kegiatan ini maka pola pikir para perempuan usaha kacang sangrai yang sudah dikelompokkan secara bertahap mulai berubah. Mereka sudah mulai paham bahwa selama ini sudah bertahun-tahun mereka memberikan keuntungan yang besar kepada toko saja, bukan terhadap diri sendiri. Setelah pelaksana dan kelompok mengkalkulasi keuntungan yang diperoleh kelompok mitra ini adalah lebih besar jika produk kacang sangrai dijual setelah dikemas dengan berkualitas. Hasil perhitungannya sebagai berikut:

Kemasan toples tabung dan pouch Isi tobles tabung sebanyak 1,5 liter dijual ke toko souvenir Rp 23.000,Harga pokoknya hanya Rp 15.000,- jadi keuntungan yang diperoleh per 1 toples adalah $\mathrm{Rp} 8.000$,Sedangkan kemasan Pouch isinya 1,5 liter harga pokoknya Rp 13.000,- dijual ke toko souvenir Rp 23.000,- Kemasan ini keuntungannya relative lebih besar yaitu Rp 10.000,-karena wadahnya lebih murah.

Jika dibandingkan dengan penjualan yang dilakukan sebelumnya yaitu tanpa kemasan, kacang sangrai hanya dihargai Rp 8.000,- per liter. Toko yang membeli dan mengemasnya dalam plastik yang bukan bentuk pouch dengan isi 1,5 liter dijual $\mathrm{Rp}$ 25.000 - Rp 30.000. Keuntungan mereka bias berlipat ganda. Padahal mereka hanya menambah kemasannya saja sudah meraup keuntungan yang besar.

Melihat perhitungan yang diperoleh maka ada peningkatan keuntungan oleh para pelaku usaha kacang sangrai tersebut, sehingga saat ini kelompok tersebut tetap didampingi oleh pelaksana kegiatan guna menjaga kesinambungan usaha mereka. 


\section{Penigkatan Jaringan Pemasaran dan Peluang Akses Perbankan}

Salah satu permasalahan para pelaku usaha kacang sangrai yang menjadi subjek kegiatan adalah aspek pemasaran. Hal ini terjadi karena mereka kurang mengakses pemasaran ke toko-toko souvenir di Kota Manado. Solusi yang telah diberikan melalui kegiatan Ipteks bagi Masyarakat adalah dengan menetapkan strategi mendatangi toko-toko souvenir untuk menjalin kerjasama dan berkoordinasi dengan Dinas Perindustrian dan Perdagangan Provinsi Sulawesi Utara.Produk kacang sangrai telah didistribusikan ke toko souvenir yang ada di Kota Manado dan di area bandara Samratulangi Manado. Toko-toko berminat untuk menjual produks kacang sangrai asal Kawangkoan karena selama ini sudah dikenal oleh wisatawan juga karena produk yang ditawarkan oleh kelompok sudah memiliki nomor P-IRT. Jika produk yang tidak dilengkapi dengan nomor tersebut maka toko merasa tahut untuk menjualnya.

Peluang untuk akses perbankan terjadi setelah diadakan pertemuan dengan perbankan yang difasilitasi oleh Dinas Perindustrian dan Perdagangan Provinsi Sulawesi Utara. Akses ini dapat terealisasi setelah kelompok memiliki Sertifikat penyuluhan pangan da nada pendampingan dari konsultan atau perguruan tinggi. Kelompok mitra saat ini sudah memiliki persyaratan tersebut dan sedang diproses untuk mendapatkan Kredit Usaha Rakyat melalui Bank BRI cabang Tomohon.

\section{PEMBAHASAN}

Data Kementerian Negara Koperasi dan Usaha Kecil Menengah menyingkapkan bahwa, populasi UMKM pada 2007 mencapai 49,8 juta unit atau 99,99\% dari total unit usaha di Indonesia. Tahun 2014 jumlah UMKM di Indonesia sebanyak 57,89 juta unit, atau 99,99 persen dari total jumlah pelaku usaha nasional. Sektor UMKM berkontribusi sebesar Rp 2.121,3 triliun kepada Produk Domestik Bruto (PDB) Indonesia atau 53,6\% dari total PDB Indonesia 2007. UMKM memberikan kontribusi terhadap kesempatan kerja sebesar 96,99 persen, dan terhadap pembentukan PDB sebesar 60,34 persen. Tahun 2014 kontribusi UMKM terhadap PDB 58,92 persen. Sektor itu juga menyerap tenaga kerja sebanyak 91,8 juta orang atau $97,3 \%$ dari total seluruh tenaga kerja Indonesia.. Usaha kecil sektor informal juga merupakan salah satu kekuatan pendorong terdepan dalam pembangunan ekonomi. (Soputan, 2016)

Usaha kacang sangrai yang dilakukan oleh kelompok mitra yang ada di Kelurahan Kinali I Kecamatan Kawangkoan merupakan usaha mikro yang telah dilakukan puluhan tahun secara turun temurun. Sektor usaha ini memberikan kontribusi yang berarti dalam pembangunan ekonomi khusunya di Kabupaten Minahasa. Untuk meningkatkan perannya dalam pemberdayaan ekonomi khususnya perempuan maka perlu diberikan penguatan-penguatan dalam peningkatan kapasitas mengelola usaha kearah yang lebih professional layaknya perusahaan. Dengan demikian para pelaku usaha ini dapat menikmati kesejahteraan dalam bidang ekonomi.

Konsep pemberdayaan kepada masyarakat khususnya para perempuan dalam bidang ekonomi tidak lepas dari perkembangan ilmu pengetahuan dan pembangunan yang merupakan antitesis dari pembangunan modernisasi yang menghasilkan ketergantungan masyarakat pada pemerintah dalam segala aspek kehidupan. Perempuan telah banyak memberikan sumbangan bagi perekonomian keluarga, masyarakat, baik sebagai pekerja maupun sebagai pelaku usaha. Dengan demikian jika para perempuan diberikan pemberdayaan maka potensi diri mereka dapat ditingkatkan dan menjadi berdaya atau mandiri. Menurut A. Nunuk P Murniati dalam Titik Hartini (Jurnal Perempuan 2012) mengatakan bahwa perempuan memiliki kelebihan yaitu:

1. Kekuatan perempuan (peluang yang berasal dari dalam pribadi) :

a. Kemampuan mendengarkan dan menginformasikan sesuatu yang disesuaikan dengan tindakan untuk menanggapinya (komunikator yang baik)

b. Kemampuan memperhatikan dan mempelajari hasil tindakan

c. Kemampuan menyesuaikan tindakan terhadap situasi yang mewujudkan kebijaksanaan.

d. Kemampuan mempertemukan ide yang bertentangan, sehingga mampu mencari akal untuk menyelesaikan masalah.

e. Mampu bertoleransi

f. Kemampuan berpikir panjang dalam membuat pertimbangan karena memperhitungkan nalar dan rasa (intuisi)

g. Kemampuan memecahkan masalah secara realistis, tidak bertele-tele

h. Kemampuan mencintai dan memelihara, sebab kaya akan intuisi.

2. Kesempatan perempuan (peluang yang berasal dari luar pribadi)

a. Berkembangnya kesadaran masyarakat tentang peran ekonomi perempuan, yang berarti mereka mau menghargai dan memberi kesempatan kepada perempuan untuk berkembang secara pribadi.

b. Makin banyak perempuan yang sadar akan potensinya, sehingga muncul pemimpin perempuan di berbagai bidang

c. Terbukanya kesempatan bagi perempuan untuk meningkatkan pengetahuannya melalui pendidikan.

d. Ada jalinan kerjasama yang makin luas bagi perkembangan perempuan, sehingga perempuan makin percaya diri bahwa mereka tidak sendiri.

Penelitian dari Sarban dan Mohammad Hassanzadeh (2014) menyimpulkan bahwa pendidikan memainkan 
peran yang penting untuk pemberdayaan ekonomi perempuan pedesaan di Iran. The findings suggest $a$ formal and non-formal education and training to build the economic capabilities of women in rural areas and eliminate gender stereotyping. Therefore, it should be noted that education as a catalyst for promoting skill, knowledge and attitude to promotion of rural women economic abilities and capabilities that will enable rural women to be effective in life and work, providing them with appropriate job opportunities, enhancing women's participation in the decision-making process at both macro and micro level, political participation, economic participation and power over economic resources including being able to deal with the paradoxes and conflict generated by chance equal opportunities for women as well as the empowerment of rural women through providing them with appropriate job opportunities. Selanjutnya dikatakan bahwa To promote need for self-determination, need for self-competency, selfmeaning, self-confidence, self-efficacy, selfmanagement, competency, required skills, knowledge, attitudes, consciousness enhancement and gaining access to resources as the key elements of women empowerment should be provided to the rural women

Hasil penelitian Marami Das Women Empowerment through Entrepreneurship: A Case Study of Guwahati Municipal Corporation menyimpulkan bahwa $A$ nation or region can only be developed if its women are given ample opportunities. Developing entrepreneurship among women will be the right approach for empowerment of women. Kharistvalashvili (2016) menguatkan hasil penelitian ini dengan memberikan suatu kesimpulan pada penelitiannya untuk mencapai kesetaraan gender penting sekali untuk menyediakan akses yang cukup bagi perempuan pada sumber daya ekonomi dan finansial. Hal ini juga diperlukan untuk memberdayakan perempuan dan untuk memastikan pembangunan ekonomi yang berkelanjutan. Mendukung langkah-langkah yang harus diambil untuk meningkatkan partisipasi perempuan dalam pengambilan keputusan ekonomi.

Peningkatan kapasitas wirausaha perempuan harus dilaksanakan secara terus menerus sampai menjadi suatu budaya. Kapasitas yang dimiliki oleh perempuan akan membantu ketahanan ekonomi keluarga apalagi usaha tersebut dilakukan dalam rumah tangga. Kapasitas dapat meningkat jika ada kemauan dari perempuan itu sendiri dan juga harus ada peran dan intervensi dari pihak pemerintah dan swasta. Teristimewa saat ini sudah era teknologi informasi, maka diperlukan peningkatan kapasitas dalam bidang teknologi dan informasi terhadap masyarakat lebih khusus para pelaku usaha kecil perempuan yang ada di pedesaan.

\section{KESIMPULAN}

Kegiatan Ipteks bagi Masyarakat sebagai kegiatan pengabdian kepada masyarakat yang telah dilakukan, hasil karyanya dapat disimpulkan sebagai berikut:

1. Terjadi perubahan pola pikir dan perilaku anggota kelompok usaha kacang sangrai ke arah mental wirauusaha.

2. Terjadi peningkatan kualitas produk dalam hal pengemasan dan ijin P-IRT

3. Terjadi peningkatan pendapatan karena keuntungan lebih besar

4. Terjadi peningkatan perluasan pasar ke tokotoko souvenir yang ada di Kota Manado bahkan di bandara Sam Ratulangi Manado.

5. Terjalin kerjasama dengan Dinas Perindustrian dan Perdagangan Provinsi Sulawesi Utara

\section{UCAPAN TERIMA KASIH}

Penghargaan dan ucapan terima kasih penulis sampaikan kepada rector Universitas Negeri Manado Prof. Dr. J.P.A. Runtuwene, M.Si yang telah memberikan dukungan dana sehingga kegiatan pengabdian kepada masyarakat dapat dilaksanakan.

\section{DAFTAR PUSTAKA}

Kharistvalashvili Nino, 2016, Women's Role in Developing Economies: Case of Georgia, European Journal of Sustainable Development, Vol. 5 N0. 1, 47-52 Manurung Adler, 2005. Wira usaha, Bisnis UKM. Buku Kompas. Jakarta.

Sarban Vakil Heidari, Mohammad Hassanzadeh, 2014, Survey of Barriers to Rural Women Economic Empowerment in Iran, European Online Journal of Natural and Social Science, Vol. 3 No. 3, 494-500

Soputan, Grace Jenny, 2016, Pemberdayaan Ekonomi Perempuan melalui Pendidikan Kewirausahaan di Sektor informal di Kabupaten Minahasa, Laporan Penelitian, Unima

--------, 2016, Perempuan dan Sektor Informal, Artikel dalam Buku Reference, ASWGI

Titik Hartini, 2012, Pemberdayaan Ekonomi Perempuan: Keluar dari Kemiskinan, , Jurnal Perempuan volume 17 No. 3 September 2012 Wanita dalam Pembangunan. Penyunting Ihromi O.Yayasan Obor Indonesia. Jakarta. 